\title{
Salt stress: antioxidant activity as a physiological adaptation of onion cultivars
}

\author{
Natália Silveira Corrêa ${ }^{1}$, Juliana de Magalhães Bandeira ${ }^{1,2}$, Patrícia Marini ${ }^{1}$, \\ Isabel Cristina Gouvea de Borba ${ }^{1}$, Nei Fernandes Lopes ${ }^{1}$ and Dario Munt de Moraes ${ }^{1}$
}

Submitted: 22 October, 2012. Accepted: 28 February, 2013

\begin{abstract}
The germination and development of several plant species can be limited when those plants are grown in soils with high salinity, which reduces seedling viability and vigor, as well as activating the antioxidant defense system. The aim of this study was to evaluate germination, initial growth and activity of antioxidant enzymes (superoxide dismutase, catalase and ascorbate peroxidase) in seedlings of three onion cultivars (Madrugada, Fepagro 27 and Petroline) exposed to different concentrations of $\mathrm{NaCl}(0,40,80,120$ and $160 \mathrm{mM})$. Seedlings were evaluated for viability, vigor and antioxidant enzyme activity. The experimental procedures were completely randomized in $3 \times 5$ factorial design, with each treatment performed in triplicate, at a significance level of $5 \%$. For all cultivars, viability and vigor decreased in parallel with increasing $\mathrm{NaCl}$ concentrations, whereas antioxidant enzyme activity increased, and one cultivar (Madrugada) showed less salt tolerance than did the others. We conclude that high $\mathrm{NaCl}$ concentrations have a negative effect in the physiological quality of onion seeds, resulting in lower seedling growth rates and increased antioxidant enzyme activity, where Fepagro 27 and Petroline cultivars were more tolerant to salt stress than 'Madrugada'.
\end{abstract}

Key words: Allium cepa, growing, oxidative stress, germination, $\mathrm{NaCl}$

\section{Introduction}

The salinization of soils dedicated to agriculture, caused by the accumulation of salts in irrigation water, causes these soils to become increasingly unproductive (Lima \& Bull 2008). In Brazil, although there are few data on areas of high salinity, it is estimated that this problem affects 20 $25 \%$ of all irrigated areas (Fao 2006).

When irrigation waters have a high concentration of salts and there is no possibility of exporting these brackish waters to a sink, they can accumulate and cause damage (Santos et al. 2009). Such accumulation can limit the germination and development of various species (Barroso et al. 2010), leading to morphological, cellular, biochemical and molecular alterations that hinder the agricultural yield in response to the decrease in the water potential of the soil solution induced by the high osmolarity (Lima \& Bull 2008). In addition, ionic toxicity promotes an imbalance in the absorption of essential nutrients, causing metabolic disorders, which inhibit growth (Maia et al. 2012). Salt stress can also lead to excess intracellular production of reactive oxygen species (ROS) such as the superoxide radical $\left(\mathrm{O}_{2}{ }^{--}\right)$, the hydroxyl radical $\left(\mathrm{OH}^{-}\right)$, hydrogen peroxide $\left(\mathrm{H}_{2} \mathrm{O}_{2}\right)$, and singlet oxygen $\left({ }^{1} \mathrm{O}_{2}\right)$ (Stanisavljević et al. 2011).
The production of ROS seems to be a dynamic event during plant development, as well as a response of the plant to biotic and abiotic stress (El-Shabrawi et al. 2010). To eliminate these ROS, plants possess antioxidant defense systems, which are an important first line of defense against free radicals under stress conditions. This is the case of the antioxidant enzymes superoxide dismutase (SOD), which catalyzes the dismutation of $\mathrm{O}_{2}{ }^{--}$into $\mathrm{H}_{2} \mathrm{O}_{2}$ and $\mathrm{O}_{2}$; catalase (CAT); and ascorbate peroxidase (APX), which can cleave $\mathrm{H}_{2} \mathrm{O}_{2}$ into $\mathrm{H}_{2} \mathrm{O}$ and $\mathrm{O}_{2}$ (Deuner et al. 2011). However, this regulation can be ineffective if the stress is severe enough to considerably increase the production of ROS, which can cause a cascade of events: peroxidation of lipids, degradation of membranes, and cell death (Pacheco et al. 2007). Therefore, the balance between the production of ROS and the ability to rapidly activate the antioxidant defense system reflects the ability of a plant to endure adverse conditions, indicating its adaptation or tolerance to the imposed stress (Parida \& Das 2005; Demiral \& Turkan 2005).

Tolerance to salinity is specific for each species or cultivar. Vegetables have a high sensitivity to the effects of $\mathrm{NaCl}$ (Zhu 2002), which hinders growth because of its toxic and osmotic effects, respectively causing accumulation of ions in the protoplasm and physiological drought (Kader \& Lindeberg 2010; Deuner et al. 2011).

\footnotetext{
${ }^{1}$ Universidade Federal de Pelotas, Instituto de Biologia, Departamento de Botânica, Programa de Pós-Graduação em Fisiologia Vegetal, Capão do Leão, RS, Brazil ${ }^{2}$ Author for correspondence: bandeira_jm@hotmail.com
} 
The onion is the second most widely cultivated horticultural specie in the world, and approximately $9 \%$ of all onion production occurs in Latin American countries (Recabarren 2009). In Brazil, the onion is the third most important vegetable crop, occupying $58,482 \mathrm{ha}$, with a production of $1,352.295$ tons and a mean yield of $23,123 \mathrm{~kg} \mathrm{ha}^{-1}$ (IBGE 2012). The southern and southeastern regions are the main onion producers, responsible for approximately $82 \%$ of the national production (Resende \& Costa 2007). The state of Rio Grande do Sul is the second largest producer in Brazil, after the state of Santa Catarina, and has 10,692 ha of crops and a total production of 201,532 tons (IBGE 2012). Since in the south of the state of Rio Grande do Sul the salinity of irrigation water can affect the corps of the coastal plains adjacent to the Laguna dos Patos, the culture is subject to salt stress (Marcolin et al. 2005).

Considering this context and the economic importance of onion crops for the southern region of Brazil, where the irrigation water is frequently saline, the aim of this study was to evaluate the seed germination, initial growth and antioxidant responses of onion seedlings exposed to different concentrations of $\mathrm{NaCl}$.

\section{Material and methods}

This study was conducted at the Laboratory of Seed Physiology and in a greenhouse belonging to the Department of Botany of the Universidade Federal de Pelotas. We used onion (Allium cepa L.) seeds of the cultivars Fepagro 27, Madrugada, and Petroline, obtained from FEPAGRO (Fundação Estadual de Pesquisa Agropecuária), RS/Brazil. The seeds were subjected to salt stress (exposure to solutions of $0,40,80,120$, and $160 \mathrm{mM} \mathrm{NaCl}$ ).

For the analyses of viability and vigor, the onion seeds were sown in plastic germination boxes $\left(\right.$ gerbox $\left.^{\circledR}\right)$, with two leaves of blotting paper and the different $\mathrm{NaCl}$ solutions at 2.5 times the dry weight of the paper, and kept in a germinator at $20^{\circ} \mathrm{C}$. Following the rules for seed analyses established by the Brazilian Ministry of Agriculture, Animal Husbandry, and Supply (Brasil 2009), we conducted a germination test (GT) with four 50 -seed sub-samples, performed in triplicate, for a total of 600 seeds per treatment for each cultivar, the results of which were obtained on the twelfth day after sowing and are given in germination percentage. The first germination count (FGC) was carried out on the sixth day after sowing, simultaneous to the germination test, results were given in percentage of normal seedlings. The germination speed index (GSI) was determined simultaneous to the germination test: daily counts were conducted from the protrusion of the radicle through the seed integument until the number of emerged seedlings became constant, ending at the twelfth day, and calculated according to Maguire (1962).

The length of the shoot (shoot length) and the length of the roots (root length) were obtained by evaluating a mean of 40 seedlings per experiment at the end of the germination test. Lengths were measured with a millimeter ruler, and the results were given in $\mathrm{mm}$ seedling ${ }^{-1}$. The dry mass (DM) of the seedlings was evaluated at the end of the germination test in a drying oven at $70 \pm 2^{\circ} \mathrm{C}$ until the mass became constant, and the results were given in $\mathrm{mg}$ seedling ${ }^{-1}$.

In addition to the growth characteristics, we evaluated the activities of the antioxidant enzymes SOD (EC 1.15.1.1), APX (EC 1.11.1.11) and CAT (EC 1.11.1.6) in a spectrophotometer (Ultrospec 2100 pro UV/visible; Amersham Biosciences, Piscataway, NJ, USA), in order to determine the antioxidant metabolism of onion seedlings subjected to salt stress. At the end of the germination test we collected samples of $400 \mathrm{mg}$ of fresh plant material, which were macerated with $10 \%$ of polyvinylpolypyrrolidone, to prevent oxidation, after which were homogenized with $1.5 \mathrm{~mL}$ of an extraction buffer, $\mathrm{pH} 7.8$, comprising potassium phosphate $100 \mathrm{mM}$, ethylenediaminetetraacetic acid (EDTA) $0.1 \mathrm{mM}$, and ascorbic acid $20 \mathrm{mM}$. The material was centrifuged at $12,000 \mathrm{~g}$ for $20 \mathrm{~min}$ at $4^{\circ} \mathrm{C}$, an adaptation of the methodology described by Deuner et al. (2011). The supernatant was collected to determine the activity of enzymes and to quantify the proteins by the Bradford method (1976).

The activity of SOD was determined considering its ability to inhibit the photoreduction of Nitro-blue tetrazolium (NBT), according to Giannopolitis \& Ries (1977). To a reaction medium containing potassium phosphate $(50 \mathrm{mM}$, $\mathrm{pH} 7.8)$, we added methionine $(14 \mathrm{mM})$, EDTA $(0.1 \mu \mathrm{M})$, NBT $(75 \mu \mathrm{M})$ and riboflavin $(2 \mu \mathrm{M})$, after which we added $100 \mu \mathrm{L}$ of the enzyme extract, in a final volume of $2.0 \mathrm{~mL}$. Readings were performed in the spectrophotometer at 560 $\mathrm{nm}$. The activity unit of SOD was defined according to the quantity of enzyme required to inhibit $50 \%$ of the photoreduction of NBT under the test conditions.

The activity of APX was determined according to Nakano \& Asada (1981), with modifications, by evaluation of the oxidation rate of ascorbate for $130 \mathrm{~s}$ at $290 \mathrm{~nm}$. We used a reaction medium comprising potassium phosphate (100 mM, pH 7.0) and ascorbic acid (0.5 mM), which was incubated at $37^{\circ} \mathrm{C}$, for $10 \mathrm{~min}$, after which we added $\mathrm{H}_{2} \mathrm{O}_{2}$ $(0.1 \mathrm{mM})$ and $25 \mu \mathrm{L}$ of the enzyme extract, in a final volume of $2.0 \mathrm{~mL}$ and the reading was performed immediately.

The activity of CAT was determined following Azevedo et al. (1998), with modifications, estimated by the decrease in absorbance at $240 \mathrm{~nm}$, for a time period equal to that used in the APX test. We used a reaction medium comprising potassium phosphate $(100 \mathrm{mM}, \mathrm{pH} 7.0)$, which was incubated at $37^{\circ} \mathrm{C}$, to which we added $\mathrm{H}_{2} \mathrm{O}_{2}(12.5 \mathrm{mM})$ and $15 \mu \mathrm{L}$ of the enzyme extract, in a final volume of $2.0 \mathrm{~mL}$.

The experimental procedures were completely randomized in $3 \times 5$ factorial design, with three cultivars and five salt concentrations $(0,40,80,120$, and $160 \mathrm{mM} \mathrm{NaCl})$, performed in triplicate. The results were subjected to ANOVA and polynomial regression at the $5 \%$ significance level, with the software WinStat 2.0 (Machado \& Conceição 2007). 


\section{Results and discussion}

The germinability of the seeds of the onion cultivars subjected to salt stress was affected by the increase in $\mathrm{NaCl}$ concentration. We observed a significant interaction between cultivars and $\mathrm{NaCl}$ concentrations (Fig. 1A). The percentage of germination for Fepagro 27 and Petroline cultivars was higher than Madrugada at all concentrations of $\mathrm{NaCl}$, showing that those ones (Fepagro 27 and Petroline) exhibited higher tolerance to salt stress. The decrease in germination caused by the increase in the $\mathrm{NaCl}$ concentration was also observed in seeds of cucumber (Cucumis sativus L.) (Carvalho \& Kazama 2011) and gliricidia [(Gliricidia sepium (Jacq.) Steud.] (Farias et al. 2009). The increase in the quantity of salts in the soil or in the substrate promotes hyperosmolarity, which restricts water absorption through the seed integument, impairing the germination (Munns \& Tester 2008).

The Fepagro 27 and Petroline cultivars seeds vigor, characterized in the FGC, was higher than the vigor of cultivar Madrugada seeds (Fig. 1B), despite the significant differences. Cultivar Madrugada exhibited less vigor at all salt concentrations, indicating its high sensitivity to salt in comparison with the other cultivars. The same effect was also observed for the GSI (Fig. 1C) of this cultivar. These responses related to the vigor of Madrugada cultivar correspond to the reduction of its viability under stress, which probably led to the delay and decrease in the degradation of its reserves during germination, and, consequently, hampered its development (Fig. 1D, 1E and 1F). Similar results were obtained in a study involving barley (Hordeum vulgare L.) seeds, in which Silva et al. (2007) described a reduction in the FGC caused by the addition of salt to the irrigation water. Dantas et al. (2007) considered this an efficient method for the prediction of the vigor and the differentiation of the salt tolerance of cultivars of bean (Phaseolus vulgaris L.). Studies of sorghum (Sorghum bicolor L., Moench) showed an accentuated decrease in the GSI at a concentration of $75 \mathrm{mM} \mathrm{NaCl}$ (Oliveira \& Gomes-Filho 2009), supporting our results.

The shoot length and root length of the seedlings originating from the germination test (Fig. 1D and 1E) had similar responses to the test variables, as well as to the GT, FGC and GSI (Fig. 1A, 1B, and 1C, respectively), with a decrease in the length of both parts according to the increase in $\mathrm{NaCl}$ concentration. Petroline cultivar had a decrease in shoot length according to the decrease in salt concentration. In contrast, the decrease in the length of the shoot of Fepagro 27 and Madrugada cultivars began at the concentrations of $121 \mathrm{mM}$ and $29.11 \mathrm{mM}$, respectively. This indicates that, concerning the length of the shoot, cultivar Fepagro 27 was the least affected by the low salt concentrations. In a similar study with melon (Cucumis melo L.), a decrease in the growth of the shoots and the roots in parallel with increases in salt concentration in the irrigation water was also observed (Freitas et al. 2006).
The smaller size of the seedlings in solutions with higher salt concentrations can be explained by the fact that, as the seeds absorb water with highly soluble salts, these salts become toxic and, consequently, cause physiological disturbances, decreasing the water potential and the germinability of the seeds (Carvalho \& Kazama 2011). In addition to the toxicity, the reduction in growth, characterized by the decrease in the length of the plant and less accumulation of dry mass, can also be promoted by the decrease of osmotic potential, which causes a water deficit, alterations in the balance of $\mathrm{K}^{+} / \mathrm{Na}^{+}$, and other nutrients (Willadino \& Camara 2010).

With the increase in the salinization of the irrigation water, there was a decrease in the accumulation of dry mass of the seedlings of the three onion cultivars (Fig. 1F). Petroline cultivar had the highest tolerance to salt stress, exhibiting a decrease in the accumulation of dry mass at concentrations above $58.83 \mathrm{mM} \mathrm{NaCl}$, reaching 62.83 mg of dry mass, while Madrugada cultivar had its highest accumulation of dry mass, $19.48 \mathrm{mg}$, at the concentration of $35.5 \mathrm{mM}$, and for Fepagro 27 cultivar, the accumulation of dry mass was inversely proportional to the increase in $\mathrm{NaCl}$ concentration.

The problems caused by salt stress, as seen in the dry mass analysis, indicate that salinity decreases biomass production, in addition to altering the partition of photoassimilates between the different plant parts (Silva et al. 2007). This differential partition can contribute to the adaptation of plants to salt stress. This process compensates the reduction of the leaf area dedicated to carbon assimilation as the acceleration of the metabolic processes that are necessary for the adjustment of the plant, depending on the stress level (Munns \& Tester 2008).

The seedlings that were subjected to the higher concentrations of $\mathrm{NaCl}$ had less vigor, and this stress condition was confirmed by the increasing activity of the antioxidant defense system under the salt stress conditions of this study (Fig. 2).

Of the enzymes involved in the removal of ROS, SOD is usually the first line of defense against oxidant stress (Pompeu et al. 2008). The increase in the saline concentration of the irrigation water induced greater SOD activity (Fig. 2A). In Fepagro 27 cultivar, SOD activity was initially low, when the substrate was irrigated only with water; however, as the salt concentration increased, there was an acceleration of its activity. Therefore, the antioxidant defense system of cultivar Fepagro 27 was activated more rapidly than were those of the other cultivars, indicating a higher tolerance for salt stress (Ryang et al. 2009).

The affinity of enzymes for their substrate is a very important factor to determine the antioxidant action. Considering that CAT has a low affinity to $\mathrm{H}_{2} \mathrm{O}_{2}$, this enzyme becomes active only when its substrate is accumulated, whereas APX has a high affinity to $\mathrm{H}_{2} \mathrm{O}_{2}$ and is capable of 

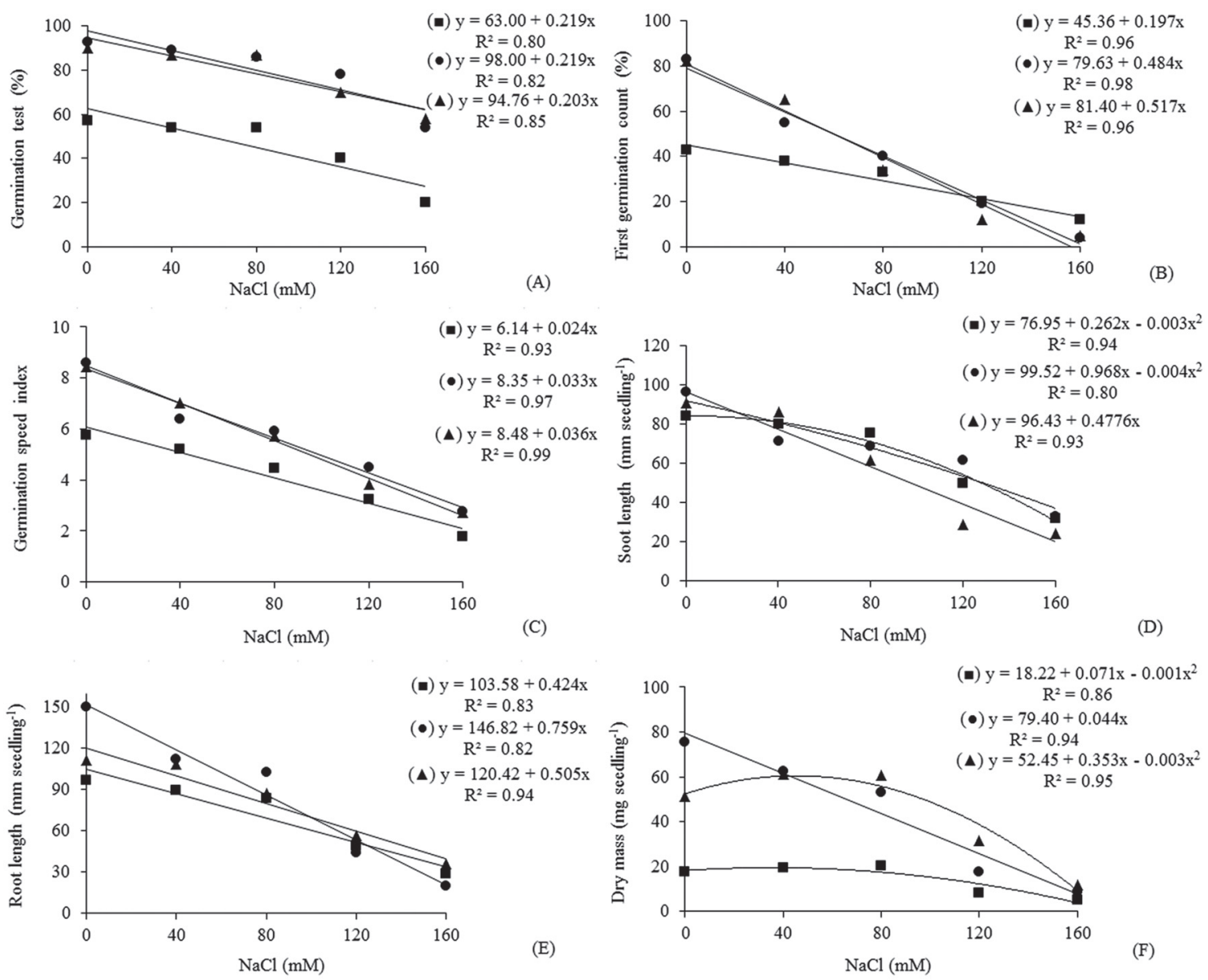

Figure 1. Percentage of germination (A), first germination count (B), germination speed index (C), shoot length (D), root length (E) and dry mass (F) of the three onion (Allium cepa L.) cultivars Fepagro 27 (-) , Madrugada (- - ) and Petroline (- $\mathbf{-}-$ ), subjected to salt stress $(0,40$, $80,120$ and $160 \mathrm{mM} \mathrm{NaCl})$.
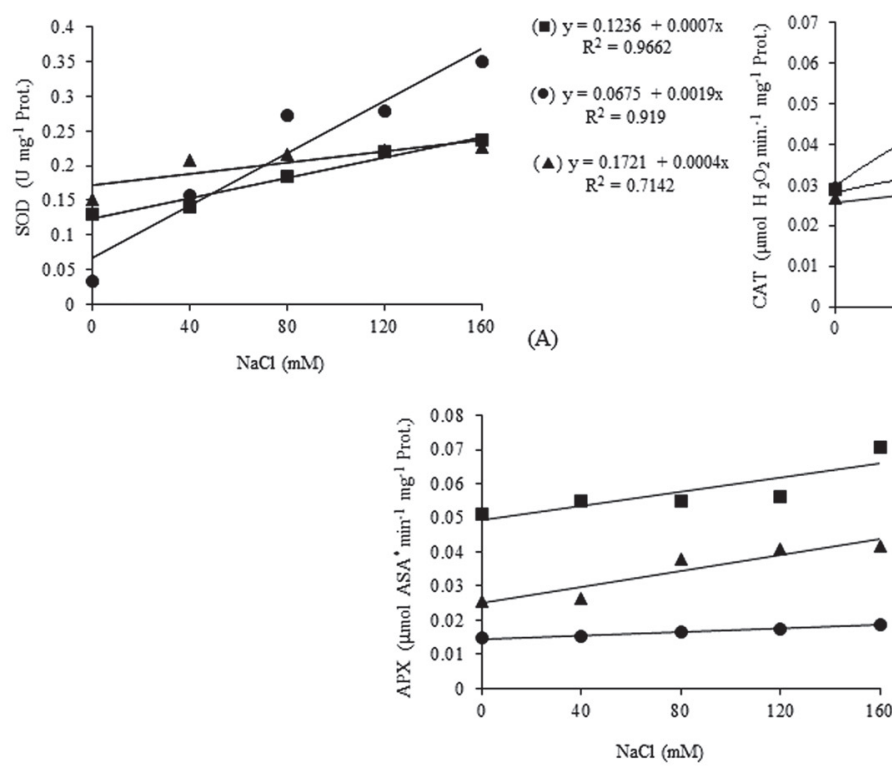

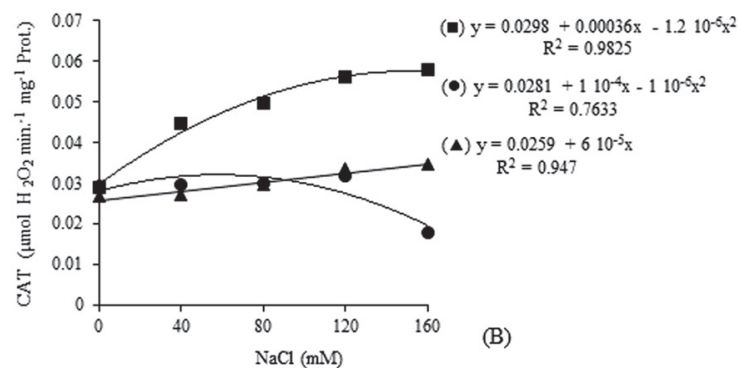

(घ) $\mathrm{y}=0.0494+0.0001 \mathrm{x}$
$\mathrm{R}^{2}=0.7249$

(•) $\mathrm{y}=0.0165$

(৯) $y=0.0251+0.0001 x$

$\mathrm{R}^{2}=0.8766$

Figure 2. Activity of the antioxidant enzymes superoxide dismutase (SOD, A), catalase (CAT, B), and ascorbate peroxidase (APX, C) in seedlings of the three onion (Allium cepa L.) cultivars Fepagro 27 (- -), Madrugada (-ם-) and Petroline (- $\mathbf{\Delta}$-), subjected to salt stress (0, 40, 80, 120, and $160 \mathrm{mM} \mathrm{NaCl}) .{ }^{\star} \mathrm{ASA}$ : ascorbic acid. 
eliminating this substrate even at low $\mathrm{H}_{2} \mathrm{O}_{2}$ concentrations (Jaleel et al. 2009).

The activity of CAT increased with the increase in the saline concentration only for Petroline cultivar (Fig. 2B), whereas for cultivars Fepagro 27 and Madrugada, CAT activity began to decrease at the concentrations of 50 and $150 \mathrm{mM} \mathrm{NaCl}$, respectively. The increase in CAT activity in stressed plants might be an adaptation to eliminate $\mathrm{H}_{2} \mathrm{O}_{2}$ (Ben Ahmed et al. 2009). Cultivar Petroline kept its antioxidant defense system more strongly activated than did the other cultivars during the stress caused by the increasing salt concentrations.

The activity of APX in Fepagro 27 cultivar was low in comparison with the other cultivars, at all concentrations (Fig. 2C), while in Madrugada and Petroline cultivars, APX activity was proportional to the increase in salt concentration, and the salt conditions applied in this study were found to be most harmful to Petroline cultivar.

The ability to maintain high SOD, CAT and APX activity under stress conditions is essential for the balance between the formation and removal of $\mathrm{H}_{2} \mathrm{O}_{2}$ within the intracellular environment (Joseph \& Jini 2011). This ability was observed in our study, considering that, in general, there was high activity of the antioxidant defense system in the seedlings with less vigor, under the stress conditions evaluated.

Therefore, high concentrations of $\mathrm{NaCl}$ exerted a negative effect in the physiological quality of onion seeds, causing lower growth rates and higher activity of the antioxidant enzymes, because of the increase in the activation of the antioxidant defense system where Fepagro 27 and Petroline cultivars presented to be more tolerant to salt stress than Madrugada cultivar.

\section{References}

Azevedo, R.A.; Alas, R.M.; Smith, J.R. \& Lea, P.J. 1998. Response of antioxidant enzymes to transfer from elevated carbon dioxide to air and ozone fumigation, in the leaves and roots of wild-type and a catalasedeficient mutant of barley. Physiologia Plantarum 104: 280-292.

Barroso, C.M.; Franke, L.B. \& Barroso, I.B. 2010. Substrato e luz na germinação das sementes de rainha-do-abismo. Horticultura Brasileira 28: 236-240.

Ben Ahmed, C.H.; Ben Rouina, B.; Sensoy, S.; Boukhris, M. \& Ben Abdallah, F. 2009. Changes in gas exchange, proline accumulation and antioxidative enzyme activities in three olive cultivars under contrasting water availability regimes. Environmental and Experimental Botany 67: 345-352.

Brasil. Ministério da Agricultura, Pecuária e Abastecimento. 2009. Regras para análise de sementes. Ministério da Agricultura, Pecuária e Abastecimento. Secretaria de Defesa Agropecuária. Brasília, DF: MAPA/ACS.

Bradford, M.M. 1976. A rapid and sensitive method for the quantification of microgram quantities of protein utilizing the principle of proteindye binding. Analytical Biochemistry 72: 248-254.

Carvalho, L.C. \& Kazama, E.H. 2011. Efeito da salinidade de cloreto de potássio $(\mathrm{KCl})$ na germinação de sementes e crescimento de plântulas de pepino (Cucumis sativus L.). Enciclopédia Biosfera, Centro Científico Conhecer - Goiânia.

Dantas, B.F.; Ribeiro, L.S. \& Aragão, C.A. 2007. Germination, initial growth and cotyledon protein content of bean cultivars under salinity stress. Revista Brasileira de Sementes 29: 106-110.
Demiral, T.; Turkan, I. 2005. Comparative lipid peroxidation, antioxidant defense systems and proline content in roots of two rice cultivars differing in salt tolerance. Environmental Experimental Botany 53: 247-257.

Deuner, C.; Maia, M.S.; Deuner, S.; Almeida, A. \& Meneghello, G.E. 2011. Viabilidade e atividade antioxidante de sementes de genótipos de feijão-miúdo submetidos ao estresse salino. Revista Brasileira de Sementes 33(4): 711-720.

El-Shabrawi, H.; Kumar, B.; Kaul, T.; Reddy, M.K.; Silngla-Pareek, S.L. \& Sopory, S.K. 2010. Redox homeostasis, antioxidant defense, and methylglyoxal detoxification as markers for salt tolerance in Pokkali rice. Protoplasma 245: 85-96.

Farias, S.G.G.; Freire, A.L.O.; Santos, D.R.S.; Bakke, I.A. \& Silva, R.B. 2009. Efeitos dos estresses hídrico e salino na germinação de sementes de gliricidia (Gliricidia sepium (Jacq.) Steud.). Revista Caatinga 22: 152-157.

FAO. 2006. Water in agriculture: opportunity untapped. Rome: Food and agriculture Organization of the United Nations.

Freitas, R.S.; Filho, J.A. \& Filho, E.R.M. 2006. Efeito da salinidade na germinação e desenvolvimento de plantas de meloeiro. Revista Verde 1: 113-12.

Giannopolitis, C.N. \& Ries, S.K. 1977. Superoxide dismutases. I. Occurrence in higher plants. Plant Physiology 59: 309-314.

IBGE. Instituto Brasileiro de Geografia e Estatística. Levantamento de Sistemas de Produção Agrícola. 2012. Rio de Janeiro, 25(2): 1-88. http://www.ibge.gov.br/home/estatistica/indicadores/agropecuaria/ lspa/lspa_201202.pdf (Acesso em 21/02/2013).

Jaleel, C.A.; Riadh, K.; Gopi, R.; Manivannan, P.; Ines, J.; Al-Juburi, H.J.; Chang-Xing, Z.; Hong-Bo, S. \& Panneerselvam, R. 2009. Antioxidant defense responses: physiological plasticity in higher plants under abiotic constraints. Acta Physiology Plant 31: 427-436.

Joseph, B. \& Jini, D. 2011. Development of Salt Stress-tolerant Plants by Gene Manipulation of Antioxidant Enzymes. Asian Journal of Agricultural Research 5: 17-27.

Kader, M.A. \& Lindberg, S. 2010. Cytosolic calcium and pH signaling in plants under salinity stress. Plant Signaling \& Behavior 5: 233-238.

Lima, M.D.B. \& Bull, L.T. 2008. Produção de cebola em solo salinizado. Revista Brasileira de Engenharia Agrícola e Ambiental 12: 231-235.

Machado, A.A. \& Conceição, A.R. 2007. WinStat - Sistema de Análise Estatística para Windows versão 2.0. Universidade Federal de Pelotas.

Maguire, J.D. 1962. Speed of germination and in selection and evaluation for seedling emergence and vigor. Crop Science 2: 176-177.

Maia, J.M.; Ferreira-Silva, S.L.; Voigt, E.L.; Macedo, C.E.C. de; Ponte, L.F.A. \& Silveira, J.A.G. 2012. Atividade de enzimas antioxidantes e inibição do crescimento radicular de feijão caupi sob diferentes níveis de salinidade. Acta Botanica Brasílica 26: 342-349.

Marcolin, E.; Anghinoni, I.; Macedo, V.M.; Genro Junior, S.A. \& Vezzani, F.M. 2005. Salinidade da cultura do arroz no Rio Grande do Sul. Revista Lavoura Arroz 53: 27-38.

Munns, R. \& Tester M. 2008. Mechanisms of salinity tolerance. Annual Review of Plant Biology 59: 651-681.

Nakano, Y. \& Asada, K. 1981. Hydrogen peroxide is scavenged by ascorbate specific peroxidase in spinach cloroplasts. Plant and Cell Physiology 22: $867-880$

Oliveira, A.B. \& Gomes-Filho, E. 2009. Germinação e vigor de sementes de sorgo forrageiro sob estresse hídrico e salino. Revista Brasileira de Sementes 31: 25-34.

Pacheco, A.C., Custódio, C.C.; Machado Neto, N.B.; Carvalho, P.R.; Pereira, D.N. \& Pacheco, J.G.E. 2007. Germinação de sementes de camomila [Chamomilla recutita (L.) Rauschert] e calêndula (Calendula officinalis L.) tratadas com ácido salicílico. Revista Brasileira de Plantas Medicinais 9: 61-67.

Parida, A.K. \& Das, A.B. 2005. Salt tolerance and salinity effects on plants: a review. Ecotoxicology and Environmental Safety 60: 324-349.

Pompeu, G.B.; Gratão, P.L.; Vitorello, V.A. \& Azevedo, R.A. 2008. Antioxidant isoenzyme responses to nickel-induced stress in tobacco cell suspension culture. Scientia Agrícola 65: 548-552.

Recabarren, P.E. 2009. Mercado Agropecuario: Situación del mercado de la cebolla 2008/09. ODEPA - Oficina de Estudios y Políticas Agrarias. Gobierno de Chile - Ministerio de Agricultura. http://www.odepa.gob. cl/odepaweb/servicios-informacion/Mercados/sep-09.pdf (Acesso em 25/02/2013). 
Resende, G.M. \& Costa, N.D. 2007. Cultivo da cebola no Nordeste: Socioeconomia. Embrapa Semi-Árido, Sistemas de Produção 3, ISSN 18070027. Versão eletrônica. http://sistemasdeproducao.cnptia.embrapa. br/FontesHTML/Cebola/CultivoCebolaNordeste/socioeconomia.htm (Acesso em 25/02/2013).

Ryang, S.; Woo, S.; Kwon, S.; Kim, S.; Lee, S.H.; Kim, K. \& Lee, D. 2009. Changes of net photosynthesis, antioxidant enzyme activities, and antioxidant contents of Liriodendron tulipifera under elevated ozone. Photosynthetica 47: 19-25.

Santos, P.R. dos; Ruiz, H.A.; Neves, J.C.L.; Almeida, E.F. de; Freire, M.B.G.S. \& Freire, F.J. 2009. Germinação, vigor e crescimento de cultivares de feijoeiro em soluções salinas. Revista Brasileira de Engenharia Agrícola e Ambiental 13: 882-889.
Silva, R.N.; Lopes, N.F.; Moraes, D.M; Pereira, A.L. \& Duarte, G.L. 2007. Physiological quality of barley seeds submitted to saline stress. Revista Brasileira de Sementes 29: 40-44.

Stanisavljević, N.S.; Nikolić, D.B.; Jovanović, Ž.S.; Samardžić, J.T.; Radović, S.R. \& Maksimović, V.R. 2011 Antioxidative enzymes in the response of buckwheat (Fagopyrum esculentum Moench) to complete submergence. Archives of Biological Sciences 63: 399-405.

Willadino, L. \& Camara, T.R. 2010. Tolerância das plantas à salinidade: aspectos fisiológicos e bioquímicos. Enciclopédia Biosfera, Centro Científico Conhecer. Goiânia.

Zhu, J.K. 2002. Salt and drought stress signal transduction in plants. Annual Review of Plant Biology 53: 247-273. 